\title{
Update on Epidemiology, Diagnosis and Control Technique of Newcastle Disease
}

\author{
Nesradin Yune* and Nejash Abdela \\ School of Veterinary Medicine, College of Agriculture and Veterinary Medicine, Jimma University, Jimma, Ethiopia
}

\begin{abstract}
Newcastle disease is an acute, contagious viral disease of birds. It is one of the most important diseases which cause great economic loss in poultry industry. The virus that cause Newcastle disease is grouped under family Paramyxoviridae in the genus Avulavirus and species avian paramyxovirus type 1 (APMV-1) or Newcastle disease virus. Based on their virulence Newcastle disease virus can be divided in to viscerotropic, neurotropic, mesogenic and lentogenic strain. Although avian paramyxovirus type 1(APMV-1) can affect many species of birds including wild birds, Chickens are highly susceptible to the disease. The objectives of this paper were to highlight the epidemiology, diagnostic technique and control measures involved in Newcastle disease. Newcastle disease is currently distributed throughout the world including Central and South America, Asia, Middle East and Africa. APMV-1 can be transmitted by inhalation or ingestion, and birds shed these viruses in both feces and respiratory secretions. The virus can also be transmitted through direct contact with infected flock and indirect contact with contaminated materials. This disease can be diagnosed based history of disease outbreak, some pathognomic sign and laboratory test such as virus isolation, serological test and molecular technique. The latter has more important being its sensitive and rapid for diagnosis of the disease. Currently both live and killed vaccines are used in many countries to control and prevent the disease in chickens. Furthermore, strict biosecurity and separation infected once from health flock are also important to control and prevent spread of disease. Generally to make poultry free of this disease, good biosecurity and continual vaccination should be maintained.
\end{abstract}

Keywords: Newcastle disease; Avian paramyxovirus type 1; Diagnosis; Vaccination

\section{Introduction}

Newcastle disease is a highly contagious economically devastating viral disease of poultry [1]. The virus that cause Newcastle disease is grouped under family paramyxoviridae, genus Avulavirus and species Newcastle disease virus or avian paramyxovirus type 1 (APMV-1) [2,3]. The genus of this virus has RNA nucleotide, enveloped, single-stranded (SS) and has negative sense [4]. The avian paramyxovirus contain six structural protein matrix $(\mathrm{M})$, RNA polymerase $(\mathrm{L})$, phosphoprotin $(\mathrm{P})$, nucleoprotein $(\mathrm{NP})$, hemagglutinin neuraminidase $(\mathrm{NH})$ and fusion $(\mathrm{F})$ $[5,6]$. Protein $\mathrm{V}$ and $\mathrm{W}$ are additionally encoded by RNA editing of $\mathrm{P}$ protein [5]. Paramyxovirus type 1 can cause disease in birds of all types, sex and age [1].

Based on their virulence avia paramyxovirus (APMV-1) has been divided in to three or more pathotypes. Velogenic neurotropic strain typically associated with neurological and respiratory sign. Velogenic viscerotropic strain typically associated with gastrointestinal lesion. These two strains are more virulent. Mesogenic strain is moderate virulence while, lantogenic strains is the least virulence and used for vaccine preparation [3].

The disease was first observed in 1926 on the Indonesia island of Java then, later, it was found in various parts of the world [7]. Newcastle disease is endemic much of Asia, Africa and the Middle East, and some countries in Central and South America [3]. Newcastle disease can infect many species of birds, but the effects of the disease vary with different species. For example, ducks and gees are least sensitive and chickens are more sensitive [8]. Newcastle disease virus can be transmitted through direct contact with infected birds and secretion from mouth, noise and eyes of infected bird. Contaminated materials, feed and water can spread disease [9]. NCD can be diagnosed based on history of disease, sign and laboratory examination [10].

Only diagnosis based on clinical sign have not accurate because it resemble highly pathogenic avian flue [11]. Laboratory diagnosis for Newcastle disease includes virus isolation, serological and molecular test. Enzyme linked immune-sorbent assay(ELISA), virus neutralization test, and hemagglutination inhibition test, reverse-transcriptase polymerase chain reaction (RTPCR) and plaque neutralization test can be used for confirmation of the ND virus [10]. The clinical sign of Newcastle disease depends on strain of virus. Some virus strain attack respiratory system other affect nerve system or digestive system. The major clinical sign observed are loss of appetite, depression, weakness, greenish diarrhea, gasping, coughing, paralysis of wings and legs, corticoids and cyanosis of comb and wattle [12]. The effective way of controlling and preventing Newcastle disease is continual vaccination program using currently available vaccine. Implementing the effective biosecurity procedures is also very important to prevent the disease [13]. Despite, the huge economic impact of this disease there is scarcity of information. Therefore, the main objective of this review is to highlight the epidemiology, diagnostic technique and control measures involved in Newcastle disease.

\section{General Information on Newcastle Disease}

Newcastle disease is acute viral disease of many species of birds. NCD is economically the most important and cause loss in poultry industries

*Corresponding author: Nesradin Yune, School of Veterinary Medicine College of Agriculture and Veterinary Medicine, Jimma University, Jimma Ethiopia, Tel: +251924124547; E-mail: Nesradin.90@gmail.com

Received February 17, 2017; Accepted March 03, 2017; Published March 06, 2017

Citation: Yune N, Abdela N (2017) Update on Epidemiology, Diagnosis and Control Technique of Newcastle Disease. J Vet Sci Technol 8: 429. doi: 10.4172/2157-7579.1000429

Copyright: @ 2017 Yune N, et al. This is an open-access article distributed under the terms of the Creative Commons Attribution License, which permits unrestricted use, distribution, and reproduction in any medium, provided the original author and source are credited. 
[14]. The virus that cause Newcastle disease is grouped under family paramyxoviridae, genus Avulavirus and species Newcastle disease virus or avian paramyxovirus type 1 (APMV-1) [2]. Although APMV-1 to APMV-12 serotype are there; APMV-1 is the most pathogenic serotype and is also referred to as Newcastle disease virus (NDV) [3]. Newcastle virus affect both wild and domestic avian species but their severity vary between different strains [15]. Newcastle disease found all over the world. Depending on its strain and clinical sign it causes NCD virus grouped in to four phenotypes [16,17]. Those are velogenic neurotropic NDV affects nerves and velogenic viscerotropic affect visceral organ, mesogenic cause moderate sever and lantogenic wich is the least sever of new castle virus [18].

Newcastle disease was first observed in 1926 in island of Java by Kranveld $[19,20]$. The disease has got its name from town Tyne, England and was named Ranikhet disease in Asia and India [21,22]. As studied by Spradbrow [23] and Alexander [24] the disease was observed in the same and subsequent year in other parts of Asia (India, Philippines, Korea). In 1930 it was also identified as the same virus cause different severity or cause different clinical sign [16].

\section{Epidemiology}

\section{Distribution and transmission}

Newcastle disease was distributed throughout the world. Newcastle disease is epizootics in Central and South America, Asia, and Africa while sporadic epizootics occur in Europe [25]. In in Europe Newcastle disease was reached in 1981 then spread rapidly throughout the world [26]. It is endemic in south East Asia and cause high economic loss in commercial poultry farm [27]. Newcastle disease can infect over 240 species of birds. When infected birds are introduced into susceptible flocks all birds will be infected within two to six days. The disease is transmitted through direct contact with infected or carriers birds. Transmission can also occur through contact with secretion and excretion of infected birds and contact with contaminated materials (Figure 1). Another important route of transmission is through air $[9,8]$. Fleas, rodent, insect and dog can also transmit NCD virus mechanical from infected faeces $[28,29]$.

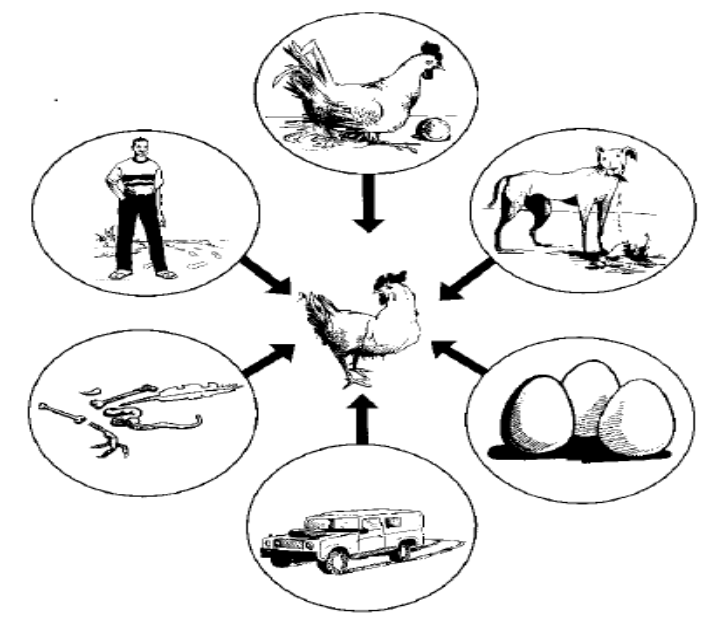

Figure 1: Newcastle disease can be transmitted from one village to anothe via people, vehicles, animals, baskets, hoes, cages and infected produce egg shells, feathers, bones, intestines, etc. [29].

\section{Risk factor}

Host risk factor: Newcastle disease can affect many species of birds. In addition to poultry, more than 230 species from more than one-half of the 50 orders of birds have been found to be susceptible to natural or experimental infections with avian paramyxoviruses. Chickens are mainly affected by Newcastle disease. Turkeys and pigeons, ducks [30,31], geese, as well as parrots and wild cormorants may also develop generalized disease, but clinical signs are rarely reported in geese and ducks [32,33]. In humans and rodents natural infection has been reported. NCD has less zoonotic importance and can cause conjunctivitis [33]. In all types of domestic poultry virulent strains of NCD virus have been found. High virulent serotype of NCD virus is not common for migratory wild birds [8].

In chicken mortality rate can reach $100 \%$. The clinical sign observed during outbreak of NCD includes, depression, diarrhea, respiratory distress, cessation of egg production, nervous sign and death [16].

Pathogen risk factor: One of the major factors that determine pathogenicity of NCD virus is that it has ability to attach and penetrate host cells. To initiate viral infection two glycoproteins haemagglutinin neuraminidase $(\mathrm{HN})$ and fusion protein $(\mathrm{F})$ are required to expose as protrusions on the surface of the virion envelope [34]. Virus can survive for some weeks in all carcass of acutely infected bird or in egg and relatively stable and can be transmitted mechanically from infected material through movement of equipment and personnel. Virus is shade in all excretion and secretion. NCD virus is readily transmitted on fomites. This virus can survive for long period of time on eggshells and especially in feces, compared to an inorganic surface (filter paper) [3]. Isolate of NCD virus differs in there virulence strain and their tissue tropism in chickens [35] (Table 1).

Environmental risk factor: The environmental persistence of these viruses is highly variable, because it can be affected by many factors such as temperature, humidity, the suspending agent and exposure to light, as well as the technique used to detect the viruses. One study reported that APMV-1 survived for up to 7 days in summer in contaminated, uncleaned poultry houses, as long as 14 days in the spring, and 30 days during the winter. Another group reported virus isolation up to 16 days after depopulation of an unvaccinated flock. However, one study found that APMV-1 remained viable for up to 255 days in a henhouse, at ambient temperatures of $-11^{\circ} \mathrm{C}\left(12^{\circ} \mathrm{F}\right)$ to $36^{\circ} \mathrm{C}\left(97^{\circ} \mathrm{F}\right)$. At $23-29^{\circ} \mathrm{C}$ $\left(73-84^{\circ} \mathrm{F}\right), \mathrm{APMV}-1$ is reported to survive in contaminated litter for 10 to 14 days, and at $20^{\circ} \mathrm{C}\left(68^{\circ} \mathrm{F}\right)$ in soil for 22 days. Virus has also been recovered from earthworms for 4 to 18 days and from experimentally contaminated lake water for 11 to 19 days [3]

\section{Diagnosis}

Newcastle disease can be diagnosed based on history, clinical sign and laboratory test. Newcastle disease clinically resembles highly pathogenic avian influenza so during outbreak rapid and accurate diagnosis is important to control and prevent dissemination of disease [11]. Laboratory diagnosis for NCD includes virus isolation, serological (enzyme-linked immune sorbent assays (ELISA), immunodiffusion test, agar gel precipitation and molecular test (Reverse transcriptionpolymerase chain reaction (RT-PCR). Isolation of the NCD virus is definitive diagnosis of NCD [38].

\section{Diagnosis based on clinical sign and lesion}

The clinical sign of NCD is depends on age, immune status of the host, tissue tropism and virulence of virus strain. Sudden high 


\begin{tabular}{|c|c|}
\hline $\begin{array}{l}\text { Types of Virulence } \\
\text { Strain }\end{array}$ & Characteristics \\
\hline $\begin{array}{l}\text { Viscerotropic } \\
\text { velogenic isolates }\end{array}$ & $\begin{array}{l}\text { Cause severe fatal diseases characterized by hemorrhagic } \\
\text { intestinal lesions }\end{array}$ \\
\hline $\begin{array}{c}\text { Neurotropic } \\
\text { velogenic isolates }\end{array}$ & $\begin{array}{l}\text { Cause acute disease characterized by nervous and } \\
\text { Respiratory signs with high mortality }\end{array}$ \\
\hline Mesogenic isolates & Cause mild disease with mortality confined to Young birds. \\
\hline Lentogenic isolate & $\begin{array}{l}\text { Cause mild or inapparent infection, coughing, gasping, } \\
\text { sneezing and rales. Mortality is Negligible }\end{array}$ \\
\hline
\end{tabular}

Table 1: The four isolates group or pathotypes on the basis of virulence and tissue tropism in chickens $[36,37]$

mortality in a flock in the absence of premonitory clinical signs occurs when susceptible species are exposed to highly virulent strain. In susceptible flocks the mortality rate in fully can reach $100 \%$ [35]. The incubation period of NCD is usually about five days. In chicken's nerve, respiratory and digestive sign may occur. The major clinical sign observed in Newcastle disease are: greenish white diarrhea, with ruffled feathers; depression in the birds and a state of prostration, a condition known as torticollis (the head turned to one side (Figure 2) and other neurological sign like paralysis of leg and wing. NCD is acute disease can cause death within 2 to 3 days $[39,40]$.

Necropsy lesions caused by velogenic APMV-1 viruses have mainly been characterized in poultry, especially chickens [3]. Viscerotropic velogenic and neurotropic velogenic strain cause hemorrhagic lesion particularly in mucosa of the proventriculus, small intestine and ceca. In respiratory tract gross lesions are not observed. Although less likely in older birds, haemorrhages of the thymus and bursa of fabriceus may also occur [41].

\section{Laboratory diagnosis}

Sample for laboratory diagnosis: The appropriate sample for diagnosis in Newcastle disease includes: tissue sample (trachea, lung, spleen, soft palate, colon, bursa and brain) witch are important for hisopathology and cloacal swabs, oro-nasal swabs and Serum sample [29]. Blood sample is usually collected from wing vein. When fresh sample is collected lung and spleen it should be wrapped in plastic and placed into cold box with ice. To do serological test haemolysed or contaminated samples should not be used because it will give unreal result [29].

Virus isolation: Virus is obligate intracellular parasite that requires living cell in order to replicate. Cultured cells, eggs and laboratory animals may be used for virus isolation. To diagnosis APM-1 infection virus isolation in embryonated eggs or cell cultures serves as important for viral isolation [42]. Cloacal and Tracheal swabs are a good sample for viral isolation of NCDV. Sample from fresh faeces may also used as an alternative. Collected sample should be transported at $\mathrm{pH}$ 7.0-7.4 in isotonic phosphate buffered saline (PBS), containing antimicrobial drugs and media protein. Higher concentrations of antibiotic should be used when collected sample is from feaces of suspected chickens [43].

Virus isolation in culture: centrifugation of sample from feces or tissue for 10 minute at temperature $25^{\circ} \mathrm{C}$ to obtain supernatanted sample and measure $0.2 \mathrm{ml}$ of sample and inoculate in to allantoic cavity of embryonated SPF fowl egg of 9-11 days' incubation then incubate for $4-7$ days at $35-37^{\circ} \mathrm{C}$. If the tests give positive result embroynated eggs will die. Finally all eggs remained of incubation should child to $4^{\circ} \mathrm{C}$ and do for haemagglutination test (HA) [43].

Serological test: In the absence of vaccination, the presence of specific antibodies against the ND virus is not necessarily that it was suffering from the disease at the time of sampling, but indicates that the bird has been infected by the virus at some time. In practice, a high antibody titre is indicative of a recent infection. NDV may be employed as an antigen in a wide range of serological tests. Although numerous serological tests may be used to detect antibodies in serum they give little information on the infecting NDV strain. Two methods are used to measure antibody titres: the haemagglutination inhibition (HI) test, and the enzyme-linked immunosorbent assay (ELISA). The most commenaly used and show accurate result is haemagglutination inhibition (HI) test [41]. For both tests, it is necessary to collect blood samples from the chickens and should be taken from the wing veins [29].

Haemagglutination inhibition test: The haemagglutination inhibition (HI) test is used most widely in ND serology; its usefulness in diagnosis depends on the vaccinal immune status of the birds to be tested and on prevailing disease conditions. HI is done based on principle that the haemagglutinin on the viral envelope can bring about the clumping of red blood cells chicken and that this can be inhibited by specific antibodies [44]. Sera from species other than chicken red blood cells can also cause clumping (agglutination), so it should be removed by adsorption of the serum with chicken RBCs determining these properties. This is done by adding $0.5 \mathrm{ml}$ of antisera to $0.025 \mathrm{ml}$ of packed chicken RBCs, shaking gently and leaving for at least 30 minutes; the RBCs are then pelleted by centrifugation at $800 \mathrm{~g}$ for 2-5 minutes and the adsorbed sera are decanted. Any pretreatment of the sera is unnecessary as Chicken sera can rarely give nonspecific positive reactions in the HI test [37].

Enzyme linked immune sorbent assay: The ELISA works on the principle of recognition of anti-NDV antibodies, attached to a plate coated with viral antigen, by antibodies produced in another species against chicken antibodies [45]. Based on different strategies for detection of NCD antibodies, including, sandwich, indirect and blocking or competitive ELISAs using MAbs there are different commercial available ELISA kites. At least one kit uses a subunit antigen. Both ELISA and HI may measure antibodies to different antigens. ELISA test; depending on system used can detect antibodies to more than one antigen but, $\mathrm{HI}$ test is probably restricted to those directed against the $\mathrm{HN}$ protein. ELISAs are reproducible and have high specificity and sensitivity; they have been found to correlate well with the HI test [45].

Molecular technique: Molecular techniques such as polymerase chain reaction (PCR) and reverse transcription-polymerase chain reaction (RT-PCR) have been used for rapid and sensitive detection for Newcastle disease [46].

Polymerase chain reaction: The duplex PCR is done based on principle that it has the ability to amplify and differentiate multiple

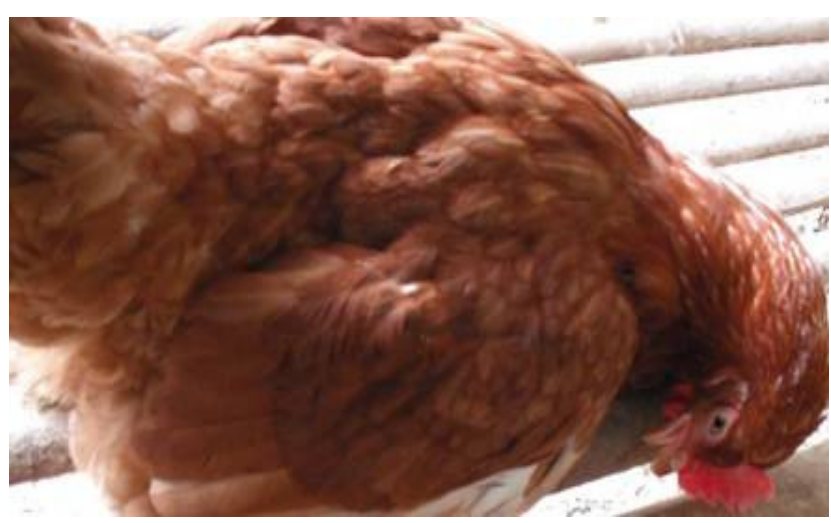

Figure 2: NDV infected layer chicken of 29 weeks of age showing nervous signs (twisted neck and paralysis) [40]. 
specific nucleic acids using polymerase enzymes [47,48]. However, those techniques can detect only one specific pathogen at a time [47]. PCR can detect virus following following the growth of virus in embryos in the laboratory and clinical specimens [49]. It has the potential to have high sensitivity and is now it is considered as the gold standard for nucleic acid detection [50]. However, PCR requires DNA as a template and the target viruses in this study have RNA as their nucleic acid. Therefore, RNA viruses require a reverse transcription step to produce single stranded complementary DNA (cDNA) through reverse transcriptase using a specific oligonucleotide primer and viral RNA as a template [50-52]

Reverse transcription-polymerase chain reaction: Molecular techniques like reverse transcription polymerase chain reaction (RTPCR) have been frequently used all over the world to detect viruses from the field samples. Reverse transcription polymerase chain reaction (RT-PCR) is used to detect RNA virus which is negative and single stranded RNA virus. There are two different configurations of the RT-PCR assay. In the two step RT-PCR configuration, the cDNA is synthesized in a different tube before performing PCR assay. In contrast a one step RT-PCR firstly synthesises the cDNA. The reverse transcriptase is inactivated and the polymerase is activated simultaneously and the PCR reaction is carried out in a single tube [53]. This is rapidly becoming the assay of choice. Several important steps need to be considered in developing an RT-PCR protocol. The first aspect is the RNA extraction. This needs to be an efficient process that can extract RNA from the samples even when it's in low concentrations and eliminate contaminants that will degrade the RNA [53]. Another important aspect is the gene being targeted and the choice of primers. This can have a profound effect on the efficacy of the assay [54]. Poorly design primers can result in mispriming and the amplification of nonspecific products or the formation of primer dimer [55].

Multiplex polymerase chain reaction: Multiplex PCR tests have been developed to allow simultaneous detection and differentiation of several avian viruses including NDV. These techniques have also been used experimentally to differentiate between velogenic, monogenic and lentogenic strains from chickens. It is applied simultaneously that required for avian infection including Newcastle disease for amplification and quantification of the virus. The primers that are specific for each virus are newly designated from the nucleoprotein gene of Newcastle disease virus. This technique helps mass amplification of the virus using common primers in the presence of fusion protein gene which increased the markedly sensitivity of the tests. At present, it should be noted that multiplexing RT-PCR assays aiming at broadening the range of virus detection frequently result in reduced sensitivity of the test compared with single target assays [56].

\section{Control Techniques of New Castle Disease}

\section{Management strategies}

The principal management procedures should include strict biosecurity measures which help in preventing the spread of infective material from house to house and from farm to farm [57]. Good biosecurity can protect poultry flocks from Newcastle disease. Avoid flocks not be to contact with domesticated poultry of unknown health status, any pet birds (particularly psittacines), and wild or feral birds (particularly cormorants, gulls and pigeons). Biosecurity measures include well ventilated houses, clean water supplies, minimizing travel on and off the facility, and disinfecting vehicles and equipment that enter the farm. Separation of infected from health flocks and proper disposal of died birds. Control of Pests such as insects and mice is also important for control measures of NCD. All in/all out breeding (one age group per farm), with disinfection between groups, is also advisable [3].

\section{Vaccination}

Vaccination is the most important method of controls and prevention of new castle disease. Currently, both inactivated and live vaccines for NCD are available around the world [58,59]. There is also thermo stable vaccine which was specifically developed to be used in village chicken [60]. We can use varieties of route for administration of live vaccine and schedules from hatching till grow-out [13]. Killed virus oil emulsion vaccines are administered parentally prior to the onset of egg production. Lentogenic virus vaccines are generally recommended in drinking water, by eye drop, by aerosol or intranasally. A vaccine using a heat-tolerant V4 strain has been developed for feeding to village chickens in countries where these constitute a significant proportion of poultry production [33]. Although proper vaccination protects the birds from clinical disease but it does not prevent virus replication and shedding, which results in a source of infection [61].

Live vaccine: Live vaccines are relatively cheap, sold as freeze dried, easy to administer and can be used for mass vaccination. These have been divided in to mesogenic and lentogenic groups with their preferred mode of administration being eye drop, beak intranasal installation, or dipping for lentogenic vaccines while mesogenic vaccine requires intramuscular injection. Drinking water and aerosol administrations can also be used [41].

In most countries, Hitchner B1 and La Sota vaccines are used and are derived from the mesogenic strain of NDV [41]. Some mesogenic vaccines may cause disease; particularly in young birds, especially if there is a dual infection with exacerbating organisms. Because of heat liable the live vaccines are also have disadvantage under village management system where transport and cold storage facilities are often inadequate [62].

Inactivated vaccine: Inactivated vaccine can be used situations unsuited for live vaccine and induce high level of protective antibody over long period of time. These vaccines are produced from infective allantoic fluid of virulent NDV treated with B-propiolactone or formalin to kill the virus and then mixed with adjuvant. The vaccine can administered ether subcutaneous or intramuscular injection [41].

Vaccination program: Vaccination program affect the duration of immunity. One of the most important considerations affecting vaccination programs is the level of maternal immunity in young chickens, which may vary considerably from batch to batch, farm to farm, and among individual chickens. For this reason, one of several strategies is employed. Either the birds are not vaccinated until 2-4 weeks of age when most of them will be susceptible, or 1-day-old birds are vaccinated by conjunctival instillation or by the application of a coarse spray. This will establish active infection in some birds that will persist until maternal immunity has waned. Revaccination is then carried out 2-4 weeks later [37].

\section{Conclusion}

Newcastle disease (NCD) is one of the most important viral diseases in poultry industry which can affect several species of birds. NCD is characterized by acute mortality marked by hemorrhagic lesions, respiratory and apparent or unapparent. Today Newcastle disease virus is found in most countries of the world and its transmission is through air, direct contact with infected or carrier birds, contact with secretion 
Citation: Yune N, Abdela N (2017) Update on Epidemiology, Diagnosis and Control Technique of Newcastle Disease. J Vet Sci Technol 8: 429. doi: $10.4172 / 2157-7579.1000429$

Page 5 of 6

and excretion of infected birds and infected materials. History, observable clinical sign and laboratory examinations are the important tools in diagnosis of NCD. Good biosecurity, separation of infected ones from health and appropriate vaccination should be practiced as control and prevention method of this disease.

\section{Acknowledgments}

We would like to acknowledge Jimma University for facility provision.

\section{Conflict of Interest}

Authors declare that they don't have any conflict of interest.

\section{References}

1. Iram N, Shah MS, Ismat F, Habib M, Iqbal M, et al. (2014) Heterologous expression, characterization and evaluation of the matrix protein from Newcastle disease virus as a target for antiviral therapies. Appl Microbio Biotechnol. 98: 1691-1701.

2. Mayo MA (2002) A summary of taxonomic changes recently approved by ICTV. Arch Virol. 147: 1655-1663.

3. Center for food security and public health (CFSPH) (2016). IOWA State University College of Veterinary Medicine. Newcastle Disease Avian Paramyxovirus-1 Infection, Goos. Paramyxovirus infection, Ranikhet disease.

4. Alexander DJ, Senne DA (2008) Newcastle disease, other avian paramyxoviruses and pneumovirus infections. In: Saif YM, Fadly AM, Glisson JR, et al. eds. lowa State University Press, USA, Dis. Poult.,12: 75-100.

5. Cattoli G, Susta L, Terregino C, Brown C (2011) Newcastle disease review of field recognition and current methods of laboratory detection. J Vet Diagn Invest. 23: 637-656.

6. Al-Habeeb MA, Mohamed MHA, Sharawi S (2013) Detection and characterization of Newcastle disease virus in clinical samples using rea time RT-PCR and melting curve analysis based on matrix and fusion genes amplification. Vet World. 6: 239-243.

7. Ashraf A, Shah MS (2014) Newcastle Disease: Present status and future challenges for developing countries. African J Microbiol Res. 8: 411-416.

8. Caupa I, Alexander DJ (2009) Avian Influenza and Newcastle Disease. A Field and Laboratory Manual. Milan: Springer-Verlag.

9. Li X, Qiu Y, Yu A, Chai T, Zhang X, et al. (2009) Degenerate primers based RT-PCR for rapid detection and differentiation of airborne chicken Newcastle disease virus in chicken houses. J Virol Methods. 158: 1-5.

10. Chaka H, Goutard F, Gil P, Abolnik C, Almeida R, et al. (2013) Serological and molecular investigation of Newcastle disease in household chicken flocks and associated markets in Eastern Shewa zone, Ethiopia. Trop Anim Health Prod 45: 705-714

11. Khan TA, Rue CA, Rehmani SF, Ahmad A, Wasilenko JL, et al. (2010) Phylogenetic and Biological Characterization of Newcastle Disease Virus Isolates from Pakistan. J Clin Microbiol. 48: 1892-1894.

12. Pazhanivel N, Balsubramaniam GA, George VT, Mohan B (2002) Study of natural outbreak of Newcastle disease in and around Namakkal. Indian Vet J. 79: $293-294$

13. Cho S, Kwon H, Kim T, Kim JH, Yoo H, et al. (2008) Characterization of a Recombinant Newcastle Disease Virus Vaccine Strain. Clin Vaccine Immunol. 15: $1572-1579$

14. Bulbule NR, Madale DS, Meshram CD, Pardeshi RB, Chawak MM (2015) Virulence of Newcastle disease virus and diagnostic challenges. Adv Anim Vet Sci. 3: 14-21.

15. Alexander DJ (1998) Newcastle disease and other avian paramyxoviruses. In: A Laboratory Manual for the Isolation and Identification of Avian Pathogens 4th edn. Edited by Swayne DE, Glisson JR, Jackwood MW, Pearson JE, Reed WM. American Association of Avian Pathologists: Kennet Square. pp: 156-163.

16. Alexander DJ, Bell JG, Alders RG (2004) A Technology Review: Newcastle Disease. With Special Emphasis on its Effect on Village Chickens. FAO Animal Production and health Paper, FAO. p: 161.
17. Engström B, Eriksson H, Fossum O, Jansson DS (2004) Compendium poultry diseases. 2nd edn. Uppsala: National Veterinary Institute.

18. Alexander DJ (2001) Gordon Memorial Lecture. Newcastle disease. Br Poult Sci. 42: 5-22.

19. Loretu K, Mkaria J (1981) Preliminary report on Newcastle disease pathotypes in Tanzania. Tanzania Vet Bull. 3: 63-66.

20. Arifin MA, Salim SH, Mel M, Abdul Karim MI, Hassan SS (2011) Optimization of Newcastle Disease Virus Production in T-flask. Proceedings of the 2nd International Conference on Biotechnology Engineering, ICBioE'11 May 17-19, Kuala Lumpur, Malaysia.

21. Doyle TM (1927) In: Rweyemamu MM, Palaya V, Win T, Sylla D (edn) Newcastle disease vaccines for Rural Africa, Pan African Veterinary Vaccine Center, Debre Zeit, Ethiopia, pp. 7-45.

22. Narayanan MS, Parthiban M, Sathiya P, Kumanan K (2010) Molecula detection of Newcastle disease virus using Flinders Molecular detection of Newcastle disease virus using Flinders Tehnology Associates-PCR Tehnology Associates-PCR. Vet Arhiv. 80: 51-60.

23. Spradbrow PB (1987) Newcastle Disease an overview. Newcastle disease in poultry, a new feed pellet vaccine, Canberra. Aust. Centre Int. Agric Res. 5: 12-18.

24. Alexander DJ (1988) Newcastle disease: Methods of spread. Newcastle disease. Boston, Kluwer Acad. Pub. pp: 1-10.

25. Naveen KA, Singh SD, Kataria JM, Barathidasan R, Dhama K (2013) Detection and differentiation of pigeon paramyxovirus serotype-1 (PPMV-1) isolates by RT-PCR and restriction enzyme analysis. Trop Anim Health Prod. 10: 01-06.

26. Mase M, Imai K, Sanada Y, Sanada N, Yuasa N, et al. (2002). Phylogenetic analysis of newcastle disease virus genotypes isolated in Japan. J Clin Microbiol. 40: 3826-3830.

27. Munir M, Zohari S, Abbas M, Berg M (2012) Sequencing and analysis of the complete genome of Newcastle disease virus isolated from a commercial poultry farm in 2010. Archive Virol. 157: 765-768.

28. Ullah S, Ashfaque M, Rahman SU, Akhtar M, Rehman A (2004) Newcastle disease virus in the intestinal contents of broilers and layers. Pak Vet J. 24: 28

29. Alders R, Spradbrow $P$ (2001) Controlling Newcastle disease in village chickens: a field manual. Australian Centre for International Agricultural Research (ACIAR)

30. Zhang S, Wang X, Zhao C, Liu D, Hu Y, et al. (2011) Phylogenetic and pathotypical analysis of two virulent newcastle disease viruses isolated from domestic ducks in China. J PLoS ONE. 6: 1-9.

31. Madadgar O, Karimi V, Nazaktabar A, Kazemimanesh M, Ghafari MM, et al. (2013) A study of Newcastle disease virus obtained from exotic caged birds in Tehran between 2009 and 2010. Avian Pathol. 42: 27-31.

32. Rima B, Alexander DJ, Billeter MA, Collins PL, Kingsbury DW, et al. (1995) Paramyxoviridae. In: Murphy FA, Fauquet CM, Bishop DH, Ghabrial AW, Jarvis GP, et al. (Eds.). Virus Taxonomy. Sixth report of the international committee in taxonomy of viruses. Springer-Verlag, Wien, pp: 268-274

33. PLAN AVE (2010) Disease Strategy Newcastle disease.

34. De Leeuw OS, Koch G, Herzog L, Ravenshorst N, Peeters BP (2005) Virulence of Differentiation of pathogenicity of avian paramyxovirus serotypes 1 . Offi Eur Uni Avian Pathol. 31: 493-499.

35. Quinn PJ, Markey BK, Carter ME, Donnelly WJ, Leonard FC (2002) Veterinary Microbiology and Microbial Disease. $4^{\text {th }}$ ed., Black well publishing company: Blackwell Science, London, UK, pp: 137-143.

36. Docherty, Douglas E (1999) Viral Diseases (Field Manual of Wildlife Diseases)

37. OIE (2012) Newcastle disease. In: Manual of Diagnostic Tests and Vaccines for Terrestrial Animals. Chapter 2.3.14.

38. Saif YM, Barnes HJ, Glisson JR, Fadly AM, McDougald LR, et al. (2005) Diseases of poultry, 11 th edn, pp: 66-78.

39. Beard CW, Hanson RP (1984) Newcastle disease. In: Diseases of poultry

40. Hasan AR, Ali MH, Siddique MP, Rahman MM, Islam MA (2012) Clinical and laboratory diagnoses of newcastle and infectious bursal diseases of chickens. Bangladesh J Vet Med. 8: 131-140.

41. Alexander DJ (2003) Newcastle disease, other Paramyxoviridae and Pneumovirus Infections. In; Diseases of Poultry. 11th edn. Iowa State press, Ames. pp: 63-100. 
Citation: Yune N, Abdela N (2017) Update on Epidemiology, Diagnosis and Control Technique of Newcastle Disease. J Vet Sci Technol 8: 429. doi: 10.4172/2157-7579.1000429

Page 6 of 6

42. Aldous EW, Alexander DJ (2001) Detection and differentiation of Newcastle disease virus (avian paramyxovirus type 1). Avian Pathol 30: 117-128.

43. Office International des Epizootics (2009) Manual of Diagnostic Testsand Vaccines for Terrestrial Animals. Newcastle disease OIE Terrestrial Manual. OIE, Paris, France, pp. 576-589.

44. Alexander DJ, Bell JG, Alders RG (1995) Newcastle disease. State Vet J. 5: 21-21.

45. Brown J, Resurreccion RS, Dickson TG (1990) The relationship between the hemagglutination-inhibition test and the enzyme-linked immunosorbent assay for the detection of antibody to Newcastle disease. Avian Dis. 34: 585-587.

46. Hewson K, Noormohammadi AH, Devlin JM, Mardani K, Ignjatovic J (2009) Rapid detection and non-subjective characterisation of infectious bronchitis virus isolates using high-resolution melt curve analysis and a mathematical model. Archives Virol. 154: 649.

47. Bellau-Pujol S, Vabret A, Legrand L, Dina J, Gouarin S, et al. (2005) Development of three multiplex RT-PCR assays for the detection of 12 respiratory RNA viruses. J Virol Methods. 126: 53-63.

48. Albert B, Bray D, Hopkins K, Johnson A, Lewis J, et al. (2004) Essential biology, edited by cell 2 nd. Garland Science.

49. Creelan JL, Graham DA, McCullough SJ (2002) Detection and Differentiation of pathogenicity of avian paramyxovirus Serotype 1 from field cases using one-step reverse transcriptase- Polymerase chain reaction. Avian Pathol. 31: 493-499.

50. Mackay IM, Arden KE, Nitsche A (2002) Real-time PCR in virology. Nucl Aci Res. 30: 1292-1305.

51. Mackay IM (2004) Real-time PCR in the microbiology laboratory. Clin Micro Infect. 10: 190-1212.

52. Turner $P$, McLennan A, Bates A, White M (2005) Molecular Biology, 3rd edn. Bios Instant Notes, edited by Hames BD, Taylor and Francis, Leeds, UK.
53. Pfaffl MW (2004) Quantification strategies in real-time PCR. A-Z of quantitative PCR. International University Line (IUL) La Jolla, CA, USA, Freising, Germany.

54. He Q, Marjamaki M, Soini H, Mertsola J, Viljanen M (1994) Primers are decisive for sensitivity of PCR. Bio Tech. 17: 82-87.

55. Abd-Elsalam KA (2003) Bioinformatic tools and guideline for PCR primer design. African J Biotechnol. 2: 91-95.

56. Tang Q, Wanga J, Bao J, Sun H, Sun Y, et al. (2012) A multiplex RT-PCR assay for detection and differentiation of avian $\mathrm{H} 3, \mathrm{H} 5$, and $\mathrm{H} 9$ subtype influenza viruses and Newcastle disease viruses. J Virol Methods. 181: 164-169.

57. Markos T, Abdela N (2016) Epidemiology and Economic Importance of Pullorum Disease in Poultry: A Review. Global Veterinaria 17: 228-237.

58. Shim JB, So HH, Won HH, Mo I (2011) Characterization of avian paramyxovirus type-1 from migratory wild birds in chickens. Avian Pathol. 40: 565-572.

59. Xiao S, Paldurai A, Nayak B, Mirande A, Collins PL, et al. (2013) Complete genome sequence of a highly virulent Newcastle disease virus currently circulating in Mexico. Genome Announc. 1: 01-02.

60. Spadbrow (1992) Newcastle disease in village chicken. Control with thermostable oral vaccine. Proceeding of an international workshop, Kuala lumpar, Malaysia. ACIAR, Canberra.

61. Chukwudi OE, Chukwuemeka ED, Mary U (2012) Newcastle disease virus shedding among healthy commercial chickens and its epidemiological importance. Pakistan Vet J. 32: 354-356.

62. Otim MO, Mukiibi GM, Christensen H, Bisgaard M (2005) Aflatoxicosis, infectious bursal disease and immune response to Newcastle disease vaccination in rural chicken. Avian Pathol. 34: 319-323. 